\title{
Det Allra bästa premiepensionssystemet? \\ - varför skadan orsakad inom det svenska premiepensionssystemet är att betrakta som state-corporate crimes ${ }^{*}$
}

\author{
Evelina Jansson, Kandidat i företagsekonomi och fil. kand. $i$ \\ kriminologi ${ }^{1}$
}

\begin{abstract}
During the last few years, it has been revealed that Allra, a company that operated within the Swedish premium pension system, has acted reprehensively. In 2017 it was reported that Allra's funds were expensive with mediocre growth and that owners at Allra benefitted at the expense of premium pension holders. Furthermore, Allra maintained subsidiaries in low tax jurisdictions that reduced tax revenues of the Swedish state and contributed to cash outflow. While this article was being written, Allra was also accused of potentially illegal transactions with a company named Oak Capital and suspected of overseeing illegal transactions between its subsidiaries in Luxembourg and Dubai. It is assumed that these transactions were made to enrich the shareholders of Allra. The current study, however, is disinterested in establishing Allra's criminal guilt. Instead, it focuses on the role that private actors and state authorities have played in Allra's harmful actions and potentially illegal transactions that have harmed premium pension holders and Swedish citizens. Using a theoretical framework proposed by Diane Vaughan (1983), the study explores issues of social structure and social relations. This is done in order to determine whether the social structure has played an important role in facilitating harm and whether states can be considered involved in this and, if so if it can be considered a case of state-corporate crime. The study concludes that states have been important for upholding and promoting the social structure and that the case can, therefore, be considered an example of state-

* The Allra best premium pension system? Why the damage caused within the Swedish premium pension system should be regarded as state-corporate crimes.

1. Arbetet med denna artikel har skett inom det av Riksbankens Jubileumsfonds finansierade projektet Business as ususal. Företags försvarsstrategier vid beskyllningar om brott (Dnr: P15-0176:1). Tack till två anonyma bedömare för värdefulla kommentarer. Tack även till Janne Flyghed, Isabel Schoultz, Enes Al Weswasi, Sandra Egelström och Gustav Grut för givande diskussioner och kommentarer.
\end{abstract}


corporate crime. However, since shareholders in leading positions in Allra have benefitted by using Allra as a tool, it is suggested that the concept of statecorporate crimes be broadened to include individuals and their self-interests.

\section{Bakgrund}

Inom kriminologin har brott av mäktiga diskuterats sedan 1940-talet när whitecollar criminality uppmärksammades (Sutherland, 1940), och under 1990-talet började state-corporate crimes att belysas (Kramer, Michalowski och Kauzlarich 2002:263). Den mest citerade definitionen av state-corporate crimes är: »Statecorporate crimes are illegal or socially injurious actions that occur when one or more institutions or political governance pursue a goal in direct cooperation with one or more institutions of economic production and distribution« (Rothe och Kauzlarich 2016:155). Denna definition utvecklades senare och skadliga handlingar beskrevs kunna vara såväl initierade som underlättade av stater (Kramer, Michalowski och Kauzlarich, 2002). Kritik har emellertid riktats mot att betrakta brott och klandervärda handlingar av företag som initierade eller underlättade av stater, och Bernat och Whyte (2016) menar istället att »... states or governments do not merely facilitate or initiate criminal and harmful practices. Rather, capitalist states produce the entirety of the social conditions that enable criminal and harmful practices to occur« (s. 77). State-corporate crimes har alltsedan det introducerades använts i en rad studier inom olika områden, exempelvis reglering av läkemedel (Griffin och Miller, 2011); miljöfrågor (Kramer och Michalowski, 2012; Smandych och Kueneman, 2010); och oljeindustri (Bradshaw, 2014). Forskning om ekonomisk brottslighet relaterat till state-corporate crimes har emellertid fått litet utrymme (Friedrichs och Rothe, 2014). Vidare har nordiska studier på området till stor del lyst med sin frånvaro, liksom studier om klandervärda handlingar inom ramen för välfärd. Konceptet har dessutom blivit kritiserat för att ofta utelämna sociala strukturer och istället fokusera på frågor om otillräcklig reglering (Whyte, 2014; Bernat och Whyte, 2016). Denna studie ämnar därför att genom en fallstudie om företaget Allra undersöka sociala strukturer relaterat till olika klandervärda handlingar i det svenska premiepensionssystemet utifrån konceptet state-corporate crimes.

Under mitten av 1990-talet arbetades en pensionsreform i Sverige fram av Socialdemokraterna, Folkpartiet, Kristdemokraterna, Centerpartiet och Moderaterna. Reformen resulterade i att privata fondbolag sedan år 2000 har haft möjlighet att erbjuda svenska premiepensionssparare sparande i fonder på Pensionsmyndighetens fondtorg (SOU 2016:61, s. 40). Pensionsspararna kan välja att investera sin premiepension (ett obligatorisk sparande som uppgår till 2,5\% av skatteplikti- 
ga ersättningar), antingen i några av de hundratals fonderna på Pensionsmyndighetens fondtorg eller i det statliga förvalsalternativet för premiepensionssparande, AP7 Såfa (Pensionsmyndigheten, 2019a). Det reformerade, fonderade premiepensionssystemet skulle utgöra ett komplement till den i stora delar ickefonderade inkomstpensionsdelen och ansågs fördelaktigt då medborgare kunde investera sin premiepension beroende på riskpreferens (SOU 2016:61, s. 41-42).

De senaste åren har dock premiepensionssystemet kantats av flera skandaler, och det har rapporterats om att fondbolag har begått såväl olagliga som klandervärda handlingar. Ett av dessa bolag var Allra som sedan år 2010, har verkat inom premiepensionssystemet. År 2013 uppdagades att Allra, då under namnet Svensk Fondservice $\mathrm{AB}$, sålde fondandelar genom aggressiva försäljningsmetoder vilket ledde till att Allra fick kritik av Konsumentombudsmannen (Ohlin, 2017). Bolaget kunde dock fortsatt verka inom premiepensionssystemet. År 2017 sparade 130.000 premiepensionssparare i någon eller flera av Allras fyra fonder, och kapitalet uppgick till cirka 19 miljarder (Dahlberg, 2017a). I början av år 2017 tog dock en intensiv nyhetsrapportering fart. Initialt rapporterades om Allrafondernas jämförelsevis dåliga tillväxt och höga avgifter. Exempelvis hade det statliga förvalsalternativet AP7 Såfa, med liknande risknivå som Allras fond Allra Modig, mellan 2012 och 2016 haft en värdeutveckling som var dubbelt så hög som värdeutvecklingen i Allra Modig. Avgifterna i Allra Modig var emellertid fyra gånger så hög (Dahlberg, 2017d). Det finns begränsningar för synliga avgifter inom premiepensionssystemet genom en rabattmodell (RIR 2018:32, s. 5), men användande av bolag registrerade utomlands medför möjligheter att ta ut högre avgifter - bland annat i Luxemburg där Allras fondbolag var förlagt (Tuvhag, 2017). Användandet av dotterbolag i Luxemburg och Dubai innebär vidare att kapital flyttas utomlands vilket inte var avsikten. Istället övervägde staten under arbetet med pensionsreformen starkare restriktioner för placering av kapital utomlands, i den mån det var möjligt med avseende på EES-avtalet, eftersom ett mål med premiepensionssystemet var tillförsel av kapital till svensk kapitalmarknad (Bet. 1993/94:SFU24, utskottet, Premiereservsystemet, para. 1).

Fallet Allra rymmer således flera klandervärda handlingar. De höga avgiftsuttagen har berikat enskilda aktieägare i synnerhet de som åven haft ledande positioner, i det icke börsnoterade Allra på bekostnad av premiepensionssparares framtida pensioner, och kapitalutflödet står i motsats till att tillföra kapital till den 
svenska kapitalmarknaden. Därtill medför användandet av SICAV²-fonder i Luxemburg (som Allra använt trots att fonderna tillhandahölls på det svenska premiepensionstorget), reducerade skatteintäkter till den svenska staten (SOU 2016:45, s. 234). Dessa legala men klandervärda handlingar kan beskrivas med hjälp av begreppet social harm (Tombs och Whyte, 2015); ett begrepp som används inom kriminologin där den klassiska legalistiska definitionen av brott inte ansetts inkludera legala handlingar som orsakar stor skada. De klandervärda handlingarna i Allra-fallet är således av kriminologiskt intresse då de lett till minskad social välfärd för premiepensionssparare liksom svenska medborgare, detta på en arena som tillhandahållits av staten och vars syfte primärt sades vara att tillgodose framtida pensionärers behov. Dessutom rymmer Allra-fallet misstänkt olagliga handlingar som mycket väl ryms inom ett traditionellt brottsbegrepp. Under 2012 genomfördes derivattransaktioner mellan Svensk Fondservice AB (som Allra tidigare hette) och ett norskt bolag, Oak Capital via fondbolaget Gustavia Fonder $\mathrm{AB}$. Med anledning av dessa transaktioner står tre personer med ledande positioner och aktieägande inom Allra åtalade, liksom Oak Capitals tidigare VD (som sedermera kom att arbeta för, och åga aktier i Allra). Rättegången inleddes i oktober 2019. Enligt åklagaren har Svensk Fondservice AB efter en uppgörelse med Oak Capital betalat överpris för värdepapper vilket resulterade i en vinst på 170 miljoner för Oak Capital, varav cirka 101 miljoner användes för att köpa aktier till överpris i ett bolag som ägdes av Svensk Fondservice ABs två grundare (Dahlberg, 2019). Brottsrubriceringarna var vid rättegångens inledning mutbrott, grovt brott och grovt tagande av muta; bestickning, grovt brott och grovt givande av muta; trolöshet mot huvudman, grovt brott och medhjälp till grov trolöshet mot huvudman, grovt brott; penninghäleri, grovt brott; och grovt bokföringsbrott (Ekobrottsmyndigheten, mål nr. B 12440-17). De fyra personerna står åtalade för olika brott, det vill säga att inte alla är misstänkta för samtliga brott. Vidare bedrev Allra år 2015 och 2016 handel med finansiella instrument mellan deras dotterbolag i Luxemburg och Dubai. Allras revisorer gjorde i mars 2017 en anmälan i vilken de ifrågasatte huruvida principen om best execution, som innebär att upphandlingar enligt lag måste ske till bästa möjliga pris, verkligen efterlevts i samband med dessa transaktioner. Dessutom ifrågasatte revisorerna att Allras bolag i Dubai använts som mellanhand vid transaktioner, liksom den höga intjäning som genererats Allras bolag i Dubai genom transaktionerna med

2. Société d'Investissement à Capital Variable: fonder med associationsrättslig struktur och rörligt aktiekapital som saknar motsvarighet i Sverige (SOU 2016:45, s. 217, 227-228). 
Allras bolag i Luxemburg (Revisorsanmälan enligt Aktiebolagslagen 9 kap. 42$44 \S \S$ bilaga 2). Vinsterna för transaktionerna som genomförts mellan Allras egna bolag misstänker åklagaren har resulterat i de utdelningar på 155 miljoner kronor som under 2016 och 2017 delades ut till ägare i Allra (Dahlberg, 2017b). Sammantaget kan summan emellertid vara högre. Enligt Småspararguidens analytiker har Allra genom påslag på transaktioner berikat sina ägare med cirka 575 miljoner kronor de senaste åren (Pensionsnyheterna 2017:2).

Allras verksamhet har emellertid varit kontrollerad av bland annat revisorer och en namnkunnig styrelse. När nyhetsrapporteringen tog fart år 2017 satt bland andra Thomas Bodström, jurist och tidigare justitieminister, och Ebba Lindsö, tidigare VD för Svenskt Näringsliv och vid tidpunkten ordförande för 6:e APfonden, i Allras styrelse. Vidare har statliga myndigheter utövat olika former av tillsyn och kontroll, däribland den svenska Pensionsmyndigheter - och Finansinspektionen i de respektive länder där Allra har varit verksamt. Således har både privata bolag och statliga instanser varit inblandade i Allra-fallet varför det är av intresse att studera fallet med avseende även på dessa aktörer. Syftet med artikeln är således att undersöka fallet Allra, de anklagelser som riktats mot företaget och de sociala strukturer som omgärdat fallet. Med sociala strukturer avses sociala relationer, lagstiftning, normer och olika former av kontroll, liksom företagsstrukturer och processer, med utgångspunkt i Vaughans (1983) teoretiska ramverk. Vidare är syftet med artikeln att undersöka relationen mellan företag och stat och om fallet kan sägas utgöra en form av state-corporate crimes. Poängteras bör emellertid att studien inte har för avsikt att utreda den straffrättsliga skulden. Frågeställningen lyder: kan de klandervärda liksom misstänkt brottsliga handlingarna i Allra-fallet sägas ha möjliggjorts genom sociala strukturer och därmed utgöra state-corporate crimes? Studien föjer därmed den på området vedertagna teoretiska traditionen att inte begränsas till den legalistiska definitionen av brott.

\section{State-corporate crimes: sociala strukturer samt kritik mot tidigare forskning}

Som nämnts $\mathrm{i}$ inledningen har kritik riktats mot forskning beträffande statecorporate crimes. Whyte (2014) har kritiserat studier på området för att ofta studera moments of rupture (identifierbara brister relaterat till specifika händelser), men utelämna den djupa politisk-ekonomiska relationen mellan stat och företag och hur staten ger företag regimes of permission (tillåtelse) att agera på tvivelaktiga sätt. Han menar att regimes of permission går att finna i hur stater sedan långt tillbaka har möjliggjort företagsstrukturer som medför begränsade skyldigheter hos ägare och individer på ledande positioner. Detta synliggörs exempelvis beträffande den corporate veil som skyddar styrelse och ledning i ansvarsfrågor - 
beslut tas av ledningen, men styrelsen är ytterst ansvarig (ibid:244). Även Bernat och Whyte (2016) har påtalat vikten av att undersöka sociala relationer och strukturer relaterat till state-corporate crimes. I en fallstudie i vilken de undersöker två oljeincidenter har de identifierat händelser som går att hänföra till hur stater har skapat sociala strukturer som bidragit till skada. De har dock identifierat få specifika beslut eller icke-beslut av stater som är hänförbara till definitionen av statecorporate crimes i termer av hur stater har initierat eller underlättat skada, och menar att dessa begrepp inte är tillräckliga för att beskriva state-corporate crimes. De menar istället att sociala relationer konstruerar reglering och att »... states play a creative and enabling role for regimes of capital accumulation ... « (s. 77), genom att exempelvis konstruera lagar, marknader och regler om företagsstrukturer (se även Tombs och Whyte, 2015). Författarna menar således att dylika faktorer är viktigare att studera relaterat till state-corporate crimes snarare än bristande reglering per se. Denna sociala, politisk-ekonomiska relation mellan stat och företag har av Rothe och Kauzlarich (2016) beskrivits som ett symbiotiskt förhållande där stater behöver företag för ekonomisk tillväxt vilket kan ge staten politisk legitimitet, och företag behöver för sin vinstmaximering att staten inte överreglerar marknader (se även Haines, 2011). Tombs och Whyte (2015) beskriver att nyliberalism och globaliseringen sedan sent 1970-tal medfört ökad makt och inflytande för företag och att stater förlitar sig på företag för produktion, innovation och ekonomisk nytta. Sammantaget - i motsats till traditionell kriminologi som ofta studerar händelser (Bernat och Whyte, 2016) - bör den sociala relationen mellan stater och företag liksom strukturer som främjar kapitalackumulation analyseras i studier om state-corporate crimes. I denna studie används därför ett teoretiskt ramverk av Diane Vaughan som möjliggör detta.

\section{Teoretiskt ramverk}

I boken Controlling Unlawful Organizational Behaviour (1983) bygger Diane Vaughan vidare på Robert K. Mertons teoretiserande om social struktur och anomie. Vaughan menar att den sociala strukturen som omger företag präglas av vinstmaximering, som är ett legitimt mål och det slutgiltigt viktigaste för företag. Hon beskriver att »(b)ecause the achievement of economic success recieves strong cultural emphasis (and is, in fact, a necessity for organizational survival) while much less emphasis is placed on the norms regulating the means to success, the norms have tended to lose the power to regulate behaviour « (1983:62-63). Att normer, även av moralisk karaktär, har förlorat sin reglerande förmåga har medfört att »(t)he absense of normative support for legitimate conduct is replaced by normative support for the illegitimate but expedient« (ibid:61). Det finns såle- 
des inga »sacred values« (ibid.), och strukturellt stöd av företags intressen från statliga liksom privata kontrollerande instanser tillsammans med konkurrens mellan företag kan leda till att tveksamt agerande upprepas och blir »business practice« (ibid:62). Kontroll av företag är dessutom ofta komplicerad på grund av faktorer i den sociala strukturen såsom geografisk spridning och komplicerade företagsstrukturer och transaktioner. Vidare bygger kontroll ofta på förtroende och utgår från den bild företagen väljer att visa (ibid:67, 68, 73-77, 89, 98). Vaughan påtalar också att statliga och privata organisationer kan anta olika roller: »(t)he government, for example, while creating special units to carry out regulatory activity, also engages in transactions with business firms as both supplier and consumer« (ibid:101). Att staten är konsument kan emellertid innebära ovilja att påföra restriktioner på företag och att företag kan utnyttja dessa frihetsgrader (ibid:102). Dessutom införlivas företags intressen i legala normer i stor utsträckning, och företag och statliga kontrollerande instanser kan ha ett symbiotiskt förhållande i vilket båda parter tjänar på den andres framgång (ibid:61, 101-103).

Även om Vaughans teoretiska ramverk främst handlar om hur den sociala strukturen producerar klandervärda handlingar på organisatorisk nivå, inkluderas även individer. Vaughan (ibid:68) påtalar att individers mål och intentioner inte behöver överensstämma med målen för organisationen de arbetar för, och att individers positioner är viktiga att studera för att begripliggöra händelser. Vaughans (1983) teoretiska ramverk rymmer därmed analys på olika nivåer vilket beskrivits viktigt för att begripliggöra state-corporate crimes (Kramer, Michalowski och Kauzlarich, 2002).

\section{Metod, material och insamling av data}

Såväl statliga dokument som nyhetsartiklar och uppgifter från Allras representanter har använts i analysen. För förståelse för premiepensionssystemet - dess syfte, uppbyggnad och kontroll - har statliga offentliga utredningar analyserats, liksom publikationer på Pensionsmyndighetens hemsida och Riksrevisionens utredning om kostnadseffektiviteten inom premiepensionssystemet. Nyhetsartiklarna är i huvudsak publicerade av Svenska Dagbladet (SvD Näringsliv), den tidning som först uppmärksammade Allra-fallet och som därefter har rapporterat löpande om fallet. På tidningens hemsida gjordes sökningar på Allra + premiepension. Debattartiklar och artiklar som rör premiepensionssystemet i allmänhet uteslöts varpå ett tiotal artiklar relevanta för förståelse om fallet återstod. Även artiklar på realtid.se, en svensk affärstidning som riktar sig till finansbranschen, har använts, med liknande sökning och urval. Även ett specialnummer från branschtidningen Pensionsnyheterna, där Allra-fallet står i fokus, ligger till grund för resultaten. 
Uppgifter från Allras representanter har av utrymmesskäl avgränsats till att gälla Allras försvar mot de anklagelser som riktats mot bolaget. Dessa är dels hämtade från Allras egen hemsida upprättad i syfte att besvara kritiken som riktats mot bolaget, dels från nyhetsartiklar där Allras VD Alexander Ernstberger bemöter kritik.

Vid genomläsningen av dokumenten, cirka 30 till antalet, stod de klandervärda handlingarna och den kontroll som omgärdat dessa i fokus. För att förstå kopplingen mellan stat och företag har olika typer av kontroll analyserats i förhållande till det inträffade: dels direkt statlig kontroll i form av lagstiftning och statliga kontrollerande instanser, dels indirekt kontroll såsom den av staten ålagda styrelsekontrollen liksom kontroll av revisorer. Vidare har sociala strukturer beträffande kontroll, mål och medel utifrån Vaughans (1983) teoretiska ramverk identifierats för att möjliggöra analys av huruvida det inträffade kan sägas utgöra state-corporate crimes som en följd av sociala strukturer.

\section{Resultat}

Denna del presenterar initialt resultat på individnivå, det vill säga de aktieägare som berikats genom Allra, vilket följs av resultat rörande organisatorisk kontroll av inblandade aktörer: revisorer, styrelse och myndigheter. Slutligen presenteras resultat på politisk-ekonomisk nivå.

\section{Vinstmaximeringssträvan - Allra och dess aktieägare}

De som synnerhet har berikats i Allra-fallet är individer på ledande positioner med ägande i Allra, däribland Alexander Ernstberger: grundare, VD och en av Allras majoritetsägare. Ernstberger menar dock i en intervju med Pensionsnyheterna att det inte fanns intentioner att berika dessa individer på bekostnad av premiepensionsspararna: »(d)et fanns inte någon sådan utpräglad drivkraft, utan som alla aktiebolag så, stipulerat av aktiebolagslagen, så ska man driva vinstdrivande verksamhet. Det delar vi med alla våra branschkollegor, inte minst bankerna« (Pensionsnyheterna 2017:15). Ernstberger försvarar även vinsterna genom en hänvisning till förfaranden i branschen överlag: »(j)ag är inte rätt person att avgöra om vi tjänar för mycket, men det jag kan säga år att våre arvoden ligger i linje med resten av branschen « (Allra, u.å. e). Dessa uttalanden kan tolkas i linje med det som Vaughan benämner som att olika företeelser kan ha strukturell support, i detta fall höga, legala vinster som har blivit »business practice« (Vaughan 1983:62). Att vinsterna är legala återkommer vid flera tillfällen i Ernstbergers försvar: »Allra är precis som bankerna ett vinstdrivande aktiebolag. Genom att vi fått ett stort antal kunders förtroende har vi också tjänat stora summor, något som 
inte är olagligt. Vi anser inte att det heller varit omoraliskt eftersom att vi har levererat en god avkastning till våra sparare ...«(Allra, u.å. c). Vidare ifrågasätter han anmälningarna och anklagelserna om att Allra har lagt på kostnader i transaktioner mellan bolagen, och menar att det inte finns någon juridisk definition av onödiga kostnader (Pensionsnyheterna 2017:13). I de sistnämnda citaten försvaras och rationaliseras således medel, det vill säga stora påslag och höga avgifter, som möjliggjort akiteägares stora utdelningar genom hänvisning till lagstiftning. Att påslagen och avgifterna är legitima, men likväl sker på bekostnad av tillväxten för premiepensionssparare, synliggör i termer av Vaughan (1983) att legala normer, såväl som moraliska, brister i reglerande förmåga liksom frånvaron av »sacred values« (s. 61).

Strukturell support i form av lagstiftning som möjliggör skadliga handlingar blir även synligt beträffande skatter. Ernstberger menar att etableringen av dotterbolaget i Dubai inte skett av skattemässiga skäl då svensk bolagsskatt tillämpats (Allra, u.å., e). Vidare hävdar Ernstberger tilsammans med en kollega och åklagare i Allra att regelverk alltid följts och att vinster (förutom vinster genererade i Luxemburg som beskattats där), har beskattats i Sverige. De menar också att användandet av kapitalmarknadsbolag är något av ett branschmässigt standardförfarande, och huruvida det exempelvis ligger i Dubai eller Luxemburg är ett affärsmässigt beslut (Ernstberger och Persson, 2017). Allras representanter uttrycker således inte Allras affärsverksamhet $\mathrm{i}$ termer av skatteplanering vilket företag sällan gör: som Evertsson (2016:204) beskrivit är denna typ av aktiviteter svåra att hantera och definiera. Oaktat intentionerna har emellertid i synnerhet dotterbolaget i Luxemburg medfört minskade skattekostnader för Allra och därmed dess aktieägare: fonderna i Luxemburg var som nämnts SICAV-fonder, och den svenska staten har utrett möjligheten att upprätta en motsvarighet i Sverige eftersom SICAV-fonder, som ofta används av skatteskäl vid internationall fonddistribution, innebär reducerade skatteintäker till den svenska staten (SOU 2016:45, s. 227, 234). Allras användande av koncernbolagen i lågskattejurisdiktionerna kan därmed återigen ses illustrera hur företag har möjlighet att begå skadliga handlingar genom legala mekanismer (Vaughan, 1983). Det är emellertid inte bara otillräcklig svensk lagstiftning som möjliggjort användande av bolagsformer, i detta fall SICAV-fonder, som skadar den svenska staten ur skattehänseende. Som Evertsson (2016:214) beskriver kan stater erbjuda lagstiftning som möjliggör skattereducering för företag, varför skatterelaterade state-corporate crimes kan betraktas initierade av de stater som tillhandahållit dylik lagstiftning. Lagstiftning kan därmed användas för, och $a v$, företag för att upprätthålla effektivitet beträffande profitmaximering (Tombs och Whyte 2015:27). Allras verk- 
samhet och de skadliga handlingarna har emellertid direkt och indirekt legitimerats av revisorer och styrelse.

\section{Revisorerna och Allra}

I Riksrevisionens rapport (RIR 2018:32) beskrivs interna revisorer vara $» \ldots$ en förlängd arm i Finansinspektionens tillsynsarbete ...« (s. 60). Den interna revisionen syftar till att utgöra ett komplement till Finansinspektionens tillsyn inte minst då revisorer har möjlighet till mer frekvent tillsyn. Finansinspektionen framhåller därför vikten av att revisorer hanterar de intressekonflikter som finns (ibid:55). Staten har således stor tilltro till revisorernas kontrollerande funktion, och revisorer kan sägas vara att betrakta som en förlängning av staten (Engdahl och Larsson 2015:1-2). Transaktionerna under år 2015 och år 2016, som i dagsläget misstänkts rymma intressekonflikter, har emellertid passerat revisorernas granskningar under flera år. På hemsidan där Allra besvarar kritik påtalar Ernstberger att revisorerna inte tidigare funnit eller påtalat några formella fel (Allra, u.å. b). Den sociala strukturen som omgett revisorernas kontroll präglas emellertid av den komplexitet som Vaughan (1983) har identifierat som kriminogen: Allra-koncernen var spridd geografiskt, och de brottsmisstänkta transaktionerna byggde på värderingar av komplicerade finansiella derivat. Dessutom bygger kontrollerande instansers arbete i stor utsträckning på förtroende och den bild företag visar upp (Vaughan, 1983). Dessa faktorer är möjliga orsaker till att de sedermera brottsmisstänkta transaktionerna kunde passera. Att helt förkasta revisorernas kontrollerande funktion vore också felaktigt: Allras revisor i Dubai uppmärksammade och ifrågasatte i januari år 2017 att transaktionerna genomförts mellan Allras dotterbolag i Luxemburg och Dubai istället för med externa parter. Vidare ifrågasatte revisorerna verksamheten i Dubai och menade att den inte överensstämde med verksamhetsplanen som presenterades i samband med etableringen år 2015 (Johansson, 2018b).

Som Ernstberger påtalar har emellertid nya, oberoende såväl externa som interna revisorer granskat de misstänkta transaktionerna efter brottsanklagelserna utan att finna brister (Allra u.å. d). Revisorernas kontrollerande funktion kan därmed ifrågasättas - Deloitte, den revisionsbyrå som var anlitad för Allras interna revision, misstänker intressekonflikter men de nya revisorerna har inte funnit felaktigheter i sin granskning. Faktum kvarstår emellertid att transaktionerna resulterat i stora utbetalningar till Allras ägare på premiepensionssparares bekostnad. Att de nya revisorerna inte funnit några formella fel innebär således att statens förlängda arm i form av (vissa) revisorer bidrar till att upprätthålla den sociala struktur där dylikt företagsagerande har strukturell support. Liknande problematik 
har emellertid inte passerat obemärkt och Riksrevisionen påtalar att den interna revisionen kontrollerande syfte har visat sig vara problematisk då revisorer i huvudsak arbetar på uppdrag av det företag de reviderar (RIR 2018:32, s. 60). Samtidigt påtalas revisorernas kontrollerande funktion, inte minst då privata revisorer, som nämnts tidigare, har möjlighet att utöva mer frekvent kontroll än Finansinspektionen (ibid:55). Att revisorernas kontrollerande funktion framhålls trots konstateranden att deras kontrollerande funktion kan vara problematisk kan tolkas i linje med hur Vaughan (1983) har påtalat att det kan finnas ovilja att påföra restriktioner på dem vars tjänster konsumeras, det vill säga att staten är konsument av revisorernas kontrollerande funktion. Staten kan således i förlängningen sägas legitimera att revisorer i sin tur kan legitimera möjligen olagliga, och i andra fall klandervärda, handlingar som upprätthåller den sociala strukturen inom premiepensionssystemet där aktieägares intressen kan ha prioritet.

Revisorerna i Allra-fallet har emellertid inte enbart haft en renodlad kontrollerande funktion på uppdrag av staten. Som Flyghed (2018) beskrivit har revisorer i allt större utsträckning även kommit att bedriva servicerådgivning, vilket har varit framträdande i Allra-fallet: »(f)örutom lagstadgad revision har Deloitte anlitats som rådgivare och konsulter i diverse redovisnings- och skattefrågor. De har varit behjälpliga och agerat bollplank i samband med etableringar i Luxemburg och Dubai« (Allra, u.å. a). Revisorerna kan därmed genom sin servicerådgivning sägas ha legitimerat etableringarna i lågskattejurisdiktionerna Luxemburg och Dubai. De kan således även indirekt sägas ha underlättat de olika klandervärda handlingarna i form av minskade skatteintäker till den svenska staten, liksom Allras höga avgifter då möjligheten till högre avgifter ökar jämfört med om fonderna varit svenskregistrerade (Tuvhag, 2017). Att kontrollera avgiftsnivåerna ingår desutom inte i revisorernas ansvarsområde (RIR 2018:32, s. 60). Med andra ord har revisorer inget ansvar över kostnadseffektiviteten för premiepensionssparare och deras agerande beträffande servicerådgivningen i Allra-fallet förefaller rimligt enligt kapitalistisk vinstmaximeringslogik. Skulle revisorerna frånsäga sig uppdrag såsom att bedriva rådgivning vid etablering av bolag i lågskattejurisdiktioner skulle de med största sannolikhet förlora kunder. Icke desto mindre bidrar revisorerna till att upprätthålla en social struktur där dylika normer ytterligare befästs. Vad revisorerna torde gjort i samband med denna rådgivning är emellertid att se till att lagstiftning, tillhandahållen av stater, efterlevs. Som Evertsson (2016) beskriver kan specifik lagstiftning beträffande skatter tillhandahållas av stater vilket kan utnyttjas av företag, och både Luxemburg och Dubai representerar lågskattejurisdiktioner. Dessa stater möjliggör således genom sin lagstiftning att företag kan begå skadliga handlingar genom legala mekanismer. Även om re- 
visorerna enligt ovan har en kontrollerande funktion, ligger emellertid det yttersta ansvaret beträffande bolagsförvaltning på styrelsen.

\section{Styrelsen, staten och legitimiteten}

Under sista året som Allra verkade inom premiepensionssystemet bestod styrelsen som nämnts av bland annat Ebba Lindsö och Thomas Bodström, som båda har varit högt uppsatta politiker i Sverige och även haft tunga uppdrag inom privat sektor. I en intervju med Ernstberger framgår att Bodström blev invald för att ge Allra trovärdighet, och »(p)å samma sätt som försäkringsrådgivaren Max Matthiessen valde in Fredrik Reinfeldt så valde vi in Thomas Bodström « (Johansson, 2018a). Trovärdigheten sett ur premiepensionssparares perspektiv kan emellertid ifrågasättas. Lindsö och Bodström godkände under sin tid i styrelsen stora utbetalningar (Dahlberg, 2017c), och kan i egenskap av styrelsemedlemmar sägas ha legitimerat förekomsten av dotterbolagen i lågskattejurisdiktionerna. Genom åren har dessutom Allras styrelse legitimerat den koncern- samt fondstruktur som möjliggjort de stora påslagen och avgifterna. Således har styrelsen bidragit till att upprätthålla den sociala strukturen där medlen, det vill säga användande av bolag i lågskattejurisdiktioner, stora påslag vid transaktioner samt höga avgifter, såväl som målen i form av vinstmaximering, normaliserats. Att de misstänkta transaktionerna inte föranlett någon uppmärksamhet från styrelsen torde dock kunna bero på att denna sällan har direkt insyn i den dagliga verksamheten, och att kontroll från styrelsen (liksom revisorers arbete), är förknippat med förtroende beträffande den bild som presenteras av företagsledningen. Icke desto mindre har styrelsen det yttersta ansvaret för bolags förvaltning vilket synliggör den företagsstruktur som staten historiskt sett har skapat och således den corporate veil som innebär att styrelser trots det yttersta ansvaret kan skyddas i ansvarsfrågor (Whyte, 2014). Att styrelsen har legitimerat Allras klandervärda handlingar, som inte ligger i linje med premiepensionssparares intressen, torde emellertid ha sin förklaring $\mathrm{i}$ att den av staten ålagda styrelsekontrollen enligt 8 kap $4 \S$ i aktiebolagslagen (SFS 2005:551) bland annat innebär att leda affärsverksamheten på mesta möjliga framgångsrika sätt för aktieägare. Styrelsen har således inget ansvar för premiepensionssparares intressen vilket är en fråga för myndigheter.

\section{Finansinspektionen, Konsumentverket och Pensionsmyndigheten}

Finansinspektionen i respektive land utövar tillsyn över fondbolagen, och Konsumentverket i Sverige värnar om konsumenternas intressen exempelvis beträffande marknadsföring. Pensionsmyndigheten administrerar fonderna och 
ingår samarbetsavtal med fondbolagen. I rapporten från Riksrevisionen framgår emellertid att:

Myndigheternas tillsynsinsatser saknar ett tydligt fokus på skäligheten i uttagna avgifter, trots att det ligger inom myndigheternas mandat att granska riktigheten i information om förvaltningskostnader, samt skäligheten i avgiftsnivån. Det saknas ett tydligt huvudmannaskap av tillsyn av premiepensionen. Ansvaret för tillsynen är fördelat mellan Finansinspektionen och Konsumentverket. Pensionsmyndigheten har inte ansvar för tillsyn men har samtidigt ansvar för att förvaltningen sker kostnadseffektivt (RIR 2018:32, s. 7).

Kontrollen inom premiepensionssystemet beträffande avgifter är med andra ord eftersatt trots flera inblandade aktörer - möjligen kan just det faktum att flera aktörer är inblandade bidragit till den oklara ansvarsfördelningen. Pensionsmyndigheten har ansvar för kostnadseffektiviteten men utövar inte tillsyn, och beträffande Finansinspektionen och Konsumentverket, som utövar tillsyn, kan »Riksrevisionen [kan] konstatera att det varken ryms inom Konsumentverkets eller Finansinspektionens tillsyn att granska eller bedöma huruvida näringsverksamheten på fondtorget bedrivs på ett kostnadseffektivt sätt« (ibid.). Allras höga avgifter kan därmed sägas ha underlättats genom statens bristande tillsyn och kontroll. Även om kontroll beträffande kostnadseffektiviteten inom premiepensionsystemet har varit eftersatt och utan riktad tillsyn utövas emellertid tillsyn av regelefterlevnad hos fondbolag, vilket dock har visat sig kunna vara problematiskt. Under 2014 kontrollerades Oak Capital, och indirekt Allra, av den norska Finansinspektionen med anledning av de sedermera misstänkt olagliga handlingarna som genomfördes år 2012. Inga oegentligheter uppdagades vid kontrollerna, och när detta problematiseras $i$ en nyhetsartikel med anledning av att dessa transaktioner nu misstänks vara brottsliga svarar Per Nordkvist, Finansinspektionens avdelningschef för marknadsuppförandetillsyn, att näringsrättsliga regler inte gav dem skäl att gå vidare (Rex, 2017a). Åklagare Thomas Hertz menar att det faktum att inga oegentligheter uppdagades kan tyda på Finansinspektionens bristande befogenheter och att näringsrättsliga regler om sekretess kan förhindra kontroller, liksom att företagen ges utrymme att välja vilken bild som presenteras eftersom Finansinspektionen huvudsakligen kontrollerar företag genom att begära in handlingar (Rex, 2017b). De näringsrättsliga reglerna liksom Finansinspektionens bristande förmåga att utöva tillsyn visar således att staten har bidragit till en social struktur som underlättar att handlingar såsom transaktionerna i Allra-fallet har kunnat passera. Vidare synliggörs den sociala relationen mellan stat och före- 
tag genom vilken stor tilltro sätts till företag att visa en rättmätig bild, och de näringsrättsliga reglerna visar att företags intressen har stark ställning.

\section{Politisk-ekonomiska förhållanden och den alltmer globaliserade världen}

Föregående stycken visar att stat och företag är sammanvävda då fondbolag inom premiepensionssystemet agerar på en arena som staten distribuerar. Dessutom synliggör pensionsreformen, genom vilken premiepensionssystemet som arena öppnades för fondbolag, att staten har satt stor tilltro till fondbolags förmåga att göra nytta inom premiepensionssystemet liksom för landets ekonomi i ett större perspektiv, och således den inom nyliberalismen vanligt förekommande tilltron till marknaden och företags förmåga att göra gott (se Tombs och Whyte, 2015; Rothe och Kauzlarich, 2016). Vidare har staten i stora delar förlitat sig på, och gett regimes of permission, till styrelser och revisorer att utöva kontroll. Det faktum att tillsynen av fondbolag inom premiepensionssystemet är eftersatt, liksom att revisorer tillåts legitimera verksamheter trots att detta visat sig vara problematiskt, kan därmed möjligen ses som tecken på statens ovilja att reglera och kontrollera bolag vars tjänster de betraktar sig vara i behov av. På samma tema går Vaughans (1983) förståelse av statens ovilja att reglera företag vars tjänster de konsumerar.

De senaste decennierna har desutom nyliberalismen präglats av ökad globalisering. I Sverige avskaffades valutaregleringen under sent 1980-tal vilket underlättade för företag att flytta kapital till lågskattejurisdiktioner (Dahlberg, 2011). Dessutom gick Sverige 1995 med i EU varpå internationell handel och användande av dotterbolag utomlands underlättades ytterligare. Reglering och tillsyn har således blivit fragmenterad och internationell, och i takt med att länder såsom Sverige har kommit att anpassa sin lagstiftning till mer internationell standard kan möjligheter till såväl reglering som tillsyn därmed sägas ha minskat. De missförhållanden som uppdagats inom premiepensionsystemet ledde emellertid till allmänhetens krav på reform, och Socialdepartementet föreslog i ett åtgärdsprogram att »inga samarbetsavtal ingås med fonder som så gott som uteslutande riktar sig mot den svenska marknaden men är etablerade i utlandet « (Socialdepartementet, 2017). Således är det möjligt att begränsa utländska fondbolag inom premiepensionssystemet och minska problemen behäftade med dessa, en reglering som emellertid inte var aktuell under Allras tid inom premiepensionssystemet. 


\section{Konklusion}

Trots intentioner om att minska kapitalutflödet; trots att SICAV-fonder medfört minskade skatteintäker; trots att fondbolag registrerade utomlands möjliggör högre avgiftsuttag; och trots att utlandsregistrerade bolag innebär minskade mandat för svenska myndigheter, präglades tiden då Allra var verksamt inom premiepensionssystemet av den svenska statens otillräckliga inskränkningar beträffande utlandsregistrerade fondbolag inom premiepensionssystemet liksom av fragmenterad kontroll där ingen myndighet haft ansvar över kostnadseffektiviteten. Allrafallet visar vidare att såväl den svenska staten, som staterna i de övriga länderna Allra verkat inom, har gett regimes of permission till revisorer och styrelse att kontrollera och skänka legitimitet till företag såsom Allra, och har således bidragit till att dessa aktörer kunnat upprätthålla den sociala struktur i vilken aktieägares mål om vinstmaximering har kunnat ske genom legala men skadliga mekanismer (även om frågan dock kvarstår huruvida transaktionerna med Oak Capital, samt transaktionerna mellan Allras egna dotterbolag, är att betrakta som legala). Sammantaget betraktas därför skadan i Allra-fallet vara möjliggjord genom sociala strukturer och relationer, och kan således sägas utgöra state-corporate crimes i likhet med hur Whytes (2014) och Bernat och Whytes (2016) studier visar att konceptet kan användas för förståelse av skada uppkommen genom djupa, strukturella relationer mellan stat och företag. Vad som varit framträdande i Allra-fallet är emellertid att enskilda invidvider har berikats genom klandervärda handlingar. Att beskriva det inträffade i termer av exempelvis occupational crimes, ett begrepp som ofta tillämpas vid studier där individer i egenskap av sina positioner begår brott mot företaget de arbetar på, skulle dock utelämna vad denna studie visat, nämligen att sociala strukturer och symbiosen mellan stater och företag kan möjliggöra för individer att begå klandervärda handlingar genom företag, som kan användas som brottsverktyg. Detta vidgade användande av begreppet state-corporate crimes att även inbegripa individers egenintresse betraktas därför vara av analytiskt värde vid liknande studier, snarare än att inkludera individer då de begått brott $\mathrm{i}$ organisationens intresse som den teoretiska traditionen på området state-corporate crimes annars påbjuder (se Kramer, Michalowski och Kauzlarich, 2002).

Allra är dessutom inte det enda premiepensionsbolaget som agerat på misstänkt olagliga eller klandervärda sätt. Falcon Funds misstänkts för att år 2013 ha flyttat premiepensionssparares kapital till andra fonder genom att via telefon ha fått tillgång till premiepensionssparares pinkoder, vilket ledde till att omkring 800 miljoner år 2018 betraktades förlorade (Brännström, 2018). På Pensionsmyndighetens hemsida framgår vidare att fonder tillhörande Fondeum och GFG blev 
avregistrerade i december 2016; Life Funds fonder avregistrerades kring i mars 2017; Advisors fonder avregistrerades i november 2017 och Solidars fonder avregistrerades i maj 2018, detta då bolagen inte bedömts lämpliga att verka inom premiepensionssystemet eller inte följt avtal. I bästa fall utgör dessa fondbolag $a$ few rotten apples, i sämsta fall utgör de toppen på ett isberg och är ytterligare indikationer på systemfel och att de sociala strukturer som omgärdar premiepensionssystemet och dess fondbolag inbjuder till brottsliga och klandervärda handlingar. Att det i Riksrevisionens rapport (RIR 2018:32, s. 6) påtalas att vissa förvaltningsformer inom premiepensionssystemet ofta brister i kostnadseffektivitet utgör emellertid ytterligare indikation på ett underliggande systemfel.

\section{Litteraturförteckning}

Allra Sverige AB (u.å, a) Deloitte och Allra: 5 års samarbete utan invändningar. http://allraini fran.se/nyheter/5-ars-samarbete-utan-invandningar-med-deloitte/ (Hämtad 2018-08-10).

Allra Sverige AB (u.å, b). Deloitte om Allra: »Inga formella fel har begåtts«. http://allrainifran. se/nyheter/deloitte-polisanmaler-allra-men-sager-att-inga-fel-begatts/ (Hämtad 2019-08-19).

Allra Sverige AB (u.å, c). Felaktigheter i bevakningen om Allra. http://allrainifran.se/nyheter/ felaktigheter-bevakningen-om-allra/ (Hämtad 2019-09-29).

Allra Sverige AB (u.å, d). Ingen revisorskritik mot Allras fondverksamhet. http://allrainifran.se/ nyheter/ingen-revisorskritik-mot-allras-fondverksamhet/ (Hämtad 2019-08-22).

Allra Sverige AB (u.å, e). VD Alexander Ernstberger svarar. http://allrainifran.se/fragor-ochsvar/ (Hämtad 2018-02-14).

Bernat, I., och Whyte, D. (2016). State-corporate crime and the process of capital accumulation: Mapping a global regime of permission from Galicia to Morecambe bay. Critical Criminology, 25(1), 71-86.

Betänkande 1993/94:SFU24. Reformering av det allmänna pensionssystemet. Stockholm: Socialförsäkringsutskottet. https://www.riksdagen.se/sv/dokument-lagar/arende/betankande/refor mering-av-det-allmanna-pensionssystemet_GH01SfU24/html (Hämtad 2019-09-29).

Bradshaw, E. (2014). »Obviously, We're All Oil Industry«: The Criminogenic Structure of the Offshore Oil Industry. Theoretical Criminology, 19: 376-395. First published online, October 10: doi:10.1177/1362480614553521.

Brännström, L. (2018). Åklagaren: så förde de över två miljarder från spararna. Expressen. 19 juni. https://www.expressen.se/dinapengar/aklagaren-sa-forde-de-over-tva-miljarder-franspararna/ (Hämtad 2019-09-29).

Dahlberg, M. (2011). Skatteparadis och utbyte av skatteupplysningar i en globaliserad värld. SvJT 383

Dahlberg, J. (2017a). Allra-skandalen: Detta är vad som hände. SvD Näringsliv. 26 juni. https://www.svd.se/allra-skandalen-detta-ar-vad-som-hande (Hämtad 2019-09-29).

Dahlberg, J. (2017b). Allras ägare har tagit ut 155 miljoner på två år. SvD Näringsliv. 22 augusti. https://www.svd.se/allras-agare-har-tagit-ut-155-miljoner-pa-tva-ar (Hämtad 2019-09-29).

Dahlberg, J. (2017c). Bodström på dubbla stolar inom penningtvätt. SvD Näringsliv. 13. oktober. https://www.svd.se/bodstrom-pa-dubbla-stolar-inom-penningtvatt (Hämtad 2019-09-29). 
Dahlberg, J. (2017d). Sparare bortdribblade i kändistätt pensionsbolag. SvD Näringsliv. 30 januari. https://www.svd.se/sparare-bortdribblade-i-det-kandistata-pensionsbolaget (Hämtad 2019-09-29).

Dahlberg, J. (2019). Emstberger i ratten: »Jag ska ge min egen bild«. SvD Nïringsliv. 30 oktober. https://www.svd.se/emstberger-i-ratten-jag-ska-ge-min-egen-bild (Hiimtad 2019-11-17).

Ekobrottsmyndigheten. (2018). Ansökan om stämning. Mål nr. B 12440-17. 1 oktober.

Engdahl, O., och Larsson, B. (2015). Duties to distrust: the decentring of economic and whitecollar crime policing in Sweden. British Journal of Criminology. doi: 10.1093/bjc/azv070.

Ernstberger, A., och Persson, D. (2017). Vad är skandalen? Aftonbladet. 19 februari. https://www.aftonbladet.se/debatt/a/AaLlr/vad-ar-skandalen. (Hämtad 2018-07-29).

Evertsson, N. (2016). Corporate tax avoidance: a crime of globalization. Crime, Law and Social Change, 66(2), 199-216.

Flyghed, J. (2018). Privatisation of intelligence-led policing. I Fyfe, Gundhus and Vrist Rønn (red). Moral Issues in Intelligence-led Policing. New York: Routledge, 204-219.

Friedrichs, D.O., och Rothe, D.L. (2014). State-corporate crime and major financial institutions: interrogating an abscence. State Crime Journal, 3(2), 146-162.

Griffin, O.H., och Miller, B.L. (2011). OxyContin and a regulation deficiency of the pharmaceutical industry: rethinking state-corporate crime. Critical Criminology, 19(3), 213-226.

Haines, F. (2011). The paradox of regulation: what regulation can achieve and what it cannot. Cheltenham: Edward Elgar, 31-60.

Johansson, S. (2018a). »Allra hade klarat sig bättre om styrelsen hade suttit kvar«. Realtid. 7 november. https://www.realtid.se/allra-hade-klarat-sig-battre-om-styrelsen-suttit-kvar-0 (Hämtad 2019-03-04).

Johansson, S. (2018b). Deloitte lägger alla kort på bordet i målet mot Allra. Realtid. 20 mars. https://www.realtid.se/deloitte-lagger-alla-kort-pa-bordet-i-malet-mot-allra (Hämtad 201808-04).

Kramer, R., och Michalowski, R. (2012). Is Global Warming a State-Corporate Crime? I R. White (red.), Climate Change from a Criminological Perspective, 71-88. New York: Springer.

Kramer, R.C., Michalowski, R.J., och Kauzlarich, D. (2002). The origins and development of the concept and theory of state-corporate crime. Crime \& Delinquency, 48(2), 263-282.

Ohlin, J. (2017). Allraskandalen - detta har hänt. 2017. SVT Nyheter. 21 mars. https://www.svt.se/ nyheter/ekonomi/allra-skandalen-detta-har-hant (Hämtad 2018-02-08).

Pensionsmyndigheten. (2016). Pensionsmyndigheten avregistrerar två fonder. https://www.pensi onsmyndigheten.se/nyheter-och-press/pressrum/pensionsmyndigheten-avregistrerar-tvafonder. (Hämtad 2019-09-29).

Pensionsmyndigheten. (2017). Advisor Världen avregistreras från pensionsmyndighetens fondtorg. https://www.pensionsmyndigheten.se/nyheter-och-press/nyheter-fondtorg/advidorvarlden-avregistreras-fran-pensionsmyndighetens-fondtorg. (Hämtad 2018-07-29).

Pensionsmyndigheten. (2018). Pensionsmyndigheten avregistrerar Allra och Life Funds från premiepensionsmyndighetens fondtorg. https://www.pensionsmyndigheten.se/nyheter-ochpress/pressrum/pensionsmyndigheten-avregistrerar-allra-och-life-funds-fran-premiepensionensfondtorg. (Hämtad 2019-09-29). 
Pensionsmyndigheten. (2019a). Premiepension - en del av den allmänna pensionen. https://www.pensionsmyndigheten.se/forsta-din-pension/sa-fungerar-pensionen/premiepen sion-en-del-av-den-allmanna-pensionen. (Hämtad 2019-11-17).

Pensionsmyndigheten. (2019b). Solidar Fonder AB avregistreras från Pensionsmyndighetens fondtorg. https://www.pensionsmyndigheten.se/nyheter-och-press/nyheter-fondtorg/soldidarfonder-ab-avregistreras-fran-pensionsmyndighetens-fondtorg. (Hämtad 2019-11-17).

Pensionsnyheterna. 2017. Han vill bli rentvådd: »Vi har inte gjort något olagligt«. Pensionsnyheterna. Nummer 9. http://www.pensionsnyheterna.se/upload/issue/analys12.pdf? (Hämtad 2019-11-17).

Revisorsanmälan enligt Aktiebolagslagen 9 kap. 42-44 $\S$.

Rex, M. (2017a). FI granskade Allras affärer 2014 - gav grönt ljus. Dagens industri. https:/www.di.se/nyheter/fi-granskade-allras-affarer-2014-gav-gront-ljus/ 30. oktober. (Hämtad 2018-08-04).

Rex, M. 2017b. Åklagaren: FI är för svagt. Dagens industri. https://www.di.se/nyheter/ aklagaren-fi-ar-for-svagt/. 31 oktober. (Hämtad 2018-07-29).

Riksrevisionen. 2018. RIR 2018:32. Förvaltningen av premiepensionssystemet - kostnadseffektivitet för spararnas bästa? Stockholm: Riksrevisionen.

Rothe, L.D., och Kauzlarich, D. (2016). Crimes of the powerful: An introduction. New York: Routledge. E-bok.

SFS 2005:551. Aktiebolagslag. Stockholm: Justitiedepartementet L1

Smandych, R., och Kueneman, R. (2010). The Canadian-Alberta Tar Sands: A Case Study of State-Corporate Environmental Crime. I R. White (red.), Global Environmental Harm: Criminological Perspectives, 87-109. Collumpton: Willan.

Socialdepartementet. (2017). Pensionsgruppen överens om handlingsplan för ett tryggt och säkert premiepensionssystem. 24 april. https://www.regeringen.se/pressmeddelanden/2017/ 04/pensionsgruppen-overens-om-handlingsplan-for-ett-tryggt-och-sakert-premiepensions system/ (Hämtad 2019-09-29).

SOU 2016:45. En hållbar, transparent och konkurrenskraftig fondmarknad. Stockholm: Finansdepartementet.

SOU 2016:61. Fokus premiepension. Stockholm: Finansdepartementet.

Sutherland, E.H. (1940). White-collar criminality. American sociological review, 5(1)., s. 1-12.

Tombs, S., och Whyte, D. (2015). The Corporate Criminal. Why corporations must be abolished. New York: Routledge. E-bok.

Tuvhag, E. (2017). Så undviker du att bli lurad när du väljer fonder. SvD Näringsliv. 23 februari. https:/www.svd.se/sa-undviker-du-att-bli-lurad-nar-du-valjer-fonder\#sida-5 /Hämtad 201903-04).

Vaughan, D. (1983). Controlling Unlawful Organizational Behaviour. Chicago: University of Chicago Press.

Whyte, D. (2014). Regimes of permission and state-corporate crime. State Crime Journal, 3(2), 237-246. 